\title{
Показники техніко-тактичних дій (одноборства, відбори, перехоплення, удари) збірної команди України в іграх 1/8 та 1/4 чемпіонату Європи 2020-2021 років
}

\section{Володимир Перевозник Володимир Паєвський}

Харківська державна академія фізичної культури, Харків, Україна

Мета: провести порівняльний аналіз показників техніко-тактичних дій (одноборства, відбори, перехоплення, удари по воротах) збірної команди України у 1/8 з командою Швейцарії та у 1/4 з командою Англії у чемпіонаті Європи.

Матеріал і методи: теоретичний аналіз і узагальнення даних науково-методичної літератури, методи педагогічних спостережень, методи математичної статистики, реєстрація та порівняльний аналіз техніко-тактичних дій (одноборства, відбори, перехоплення, удари по воротах) збірної команди України у 1/8 з командою Швеції та з командою Англії у 1/4 чемпіонату Європи 2020-2021 рр.

Результати: проведено кількісний та якісний аналіз показників техніко-тактичних дій (одноборства, відбори, перехоплення, удари по воротах) збірної команди України у 1/8 зі збірною Швеції та з командою Англії у $1 / 4$ чемпіонату Європи 2020-2021 рр.

Висновки: отримано кількісні та якісні показники виконання ТТД (одноборства, відбори, перехоплення, удари по воротах) збірної команди України у 1/8 з командою Швеції та у 1/4 з командою Англії на чемпіонаті Європи 20202021 рр., які свідчать про те, що збірна команда України мала значно вищі кількісні показники ТТД, але якість цих показників значно гірша, ніж у суперників. Порівняльний аналіз якісних показників ТТД (одноборства) збірної команди України зі збірними Швеції та Англії свідчить про те, що вони не відповідають модельним характеристикам, не дивлячись на те, що зі збірною Швеції команда України досягла позитивного результату.

Ключові слова: техніко-тактичні дії, одноборства, футболісти, коефіцієнт браку.

\section{Вступ}

Аналіз виступу найсильніших команд світу дозволяє сформувати основні тенденції, які намітилися у сучасному футболі. Футбол став швидше, жорсткіше, інтенсивніше. Підвищується значимість кожного ігрового епізоду, збільшується кількість одноборств, що у кінцевому підсумку веде до підвищення напруженості зустрічей. Кожний поєдинок потребує мобілізації фізичних сил і морально-вольових якостей $[4,13]$. Цьому свідчить останній чемпіонат Європи у 2020-2021 рр.

Розвиток футболу визначає суперництво між нападом та захистом в одному часовому просторі пріоритет віддавався захисним схемам, у другому - наступальним. Головний тренер збірної команди Франції Дідьє Дешам висловив таку думку, що головне для команди не пропустити м'яч у свої ворота, бо протягом матчу завжди буде 2-3 моменти для того, щоб забити гол [7].

Структура та критерії ефективності змагальної діяльності футболістів різного віку, кваліфікації і ігрових амплуа у наш час вивчені досить добре [1, 3, 14]. Одним з важливих компонентів техніко-тактичних дій ТТД у змагальній діяльності є захисні дії. До основних захисних дій відносяться: одноборства, відбори, перехоплення.
Однією з особливостей сучасного футболу є зростання значимості кожного ігрового епізоду. Найбільш значущими є одноборства тому, що кількість і якість цього показника багато в чому визначає успіх команди. Одноборства у грі - це боротьба за м'яч, який контролюється суперником.

Відбір - це дія, що спрямована на оволодіння м'ячем, який контролюється суперником. Існує два різновиди відбору: повний та неповний. При повному відборі - м'ячем оволодіває сам гравець, або його партнер. При неповному відборі - м'яч відбивається на визначену відстань або за бокову лінію. Перехоплення - це дія, яка спрямована на оволодіння м'ячем, який не контролюється суперником [2, 10].

Контроль ігрової діяльності футболістів дозволяє отримати об'єктивну характеристику ТТД в тих, або інших епізодах матчу та гри в цілому, а також надає можливість вносити корективи в тренувальну роботу в індивідуальному плані $[5,6,12]$.

Особливий інтерес у фахівців викликає вивчення тих ТТД, які, на їх думку, роблять найбільший внесок у результат гри. До таких ТТД фахівці відносять удари по воротах $[8,9,15]$. 
Так, у раніше проведеному дослідженні [11] авторами було встановлено, що команди високого рівня у середньому за гру виконують 13,2 ударів по воротах. 3 них: 3 гри - 11,9 ударів, після розіграшу стандартних положень - 1,3 ударів: ногою - 11,4 ударів, головою - 1,8 ударів; після відскоку м'яча від каркасу воріт, воротаря, або захисника - 2,1 ударів, після передачі м'яча від партнера - 9,8 ударів; в один дотик - 5,0 ударів, другим дотиком - 3,4 удари, після ведення м'яча - 3,4 удари; з грунту - 10,0 ударів, по м'ячу, що летить - 3,2 удари; з межі площі воріт - 0,6 ударів, із зони між площею воріт та одинадцятиметровою відміткою - 2,7 ударів, із зони однидцятиметрової відмітки та лінії штрафної площі 2,4 удари, із-за меж штрафної площі - 7,5 ударів.

Мета дослідження - провести порвіняльний аналіз показників техніко-тактичних дій (одноборства, відбори, перехоплення, удари по воротах) збірної команди України у 1/8 з командою Швеції та у 1/4 з командою Англії у фанальній частині чемпіонту Європи 2020-2021 рр.

\section{Матеріал і методи дослідження}

Реєстрація та аналіз ТТД здійснювалися в іграх чемпіонату Європи 2020-2021 рр. відповідно до відомих рекомендацій. Було проаналізовано ігри у $1 / 8$ фіналу зі збірною командою Швеції, та у $1 / 4$ фіналу зі збірною Англії. Методи дослідження: теоретичний аналіз і узагальнення даних науково-методичної літератури, методи педагогічних спостережень, методи математичної статистики.

\section{Результати дослідження}

У таблиці 1 наведено кількісні та якісні показники ТТД збірної України у 1/8 фіналу зі збірною Швеції та у 1/4 фіналу зі збірною Англії. Так, зі збірною Швеції команда України виконала 113 ТТД (одноборства, відбори, перехоплення), із них 49 - з негативним показником. Коефіцієнт браку склав - 41\%. В свою чергу збірна Швеції виконала 45 ТТД із них з негативним показником - 11, коефіцієнт браку склав - 14\%, що дорівнюється модельним показникам.
Кількість ТТД збірної України значно вище, ніж у збірної Швеції, що свідчить про те, що збірна України більше часу провела у захисних діях. Тільки в одноборствах у І-му та II-му таймах показники були однакові, хоча коефіцієнт браку у першому таймі збірної України склав 75\%, а у другому - 33\%. У той же час показники збірної Швеції у І-му таймі - 25\%, а у другому - 63\%. Якість виконання відборів та перехоплень значно краща у збірної Швеції. Кількість ТТД (одноборства, відбори, переховлення) у 1/4 збірної України зі збірною Англії склали - 82, із них з негативним покахником - 38. Коефіцієнт браку склав 46\%. Кількість ТТД (одноборства, відбори, перехоплення) збірної Англії склали - 57, з негативним показником - 11. Коефіцієнт браку - 19\%, що відповідає модельним характеристикам.

Кількість виконання одноборств у першому і другому таймі цих команд була однакова, але якість виконання краща у збірної Англії. Що стосується відборів збірної України, то у І-му таймі було виконано 23 відбори з коефіцієнтом браку - 61\%, у другому таймі - 14, із них з негативним результатом - 6. Коефіцієнт браку склав - 43\%.

Збірна Англії виконала у І-му таймі 5 відборів із негативним показником - 2. Коефіцієнт браку склав 40\%, у II-му таймі - 9 відборів, негативний показник - 1. Коефіцієнт браку - 11\%, що значно краще, ніж у збірної України.

Збірна України виконала у І-му таймі 20 перехоплень, із них з негативним показником - 5. Коефіцієнт браку склав 25\%. У ІІ-му таймі 13/5. Коефіцієнт браку - 38\%. Збірна Англії виконала у І-му таймі - 14 перехоплень, з негативним показником - 3. Коефіцієнт браку склав - $21 \%$, а у II-му таймі - 17 відборів, з негативним показником - 1, що суттєво краще, ніж результати збірної України. Таким чином, можна зробити висновок, що збірна України в іграх зі збірною Швеції та збірною Англії мала значно вищі кількісні показники ТТД, але якість цих показників значно гірша, ніж у суперників.

Аналізуючи та порівнюючи якісні показники ТТД одноборств у іграх збірної команди України зі збірними Швеції та Англії, можна зробити висновок, що вони не

Таблиця 1

Кількісні та якісні показники ТТД збірної України у 1/8 з командами Швеції та Англії у 1/4 чемпіонату Європи 2020-2021 рр.

\begin{tabular}{|c|c|c|c|c|c|c|c|c|c|c|c|c|c|c|c|}
\hline \multirow[b]{3}{*}{ № } & \multirow[b]{3}{*}{ Команди } & \multicolumn{4}{|c|}{ одноборства } & \multicolumn{4}{|c|}{ відбор } & \multicolumn{4}{|c|}{ перехоплення } & \multirow{2}{*}{\multicolumn{2}{|c|}{ Всього за гру }} \\
\hline & & \multicolumn{2}{|c|}{ I тайм } & \multicolumn{2}{|c|}{ II тайм } & \multicolumn{2}{|c|}{ I тайм } & \multicolumn{2}{|c|}{ II тайм } & \multicolumn{2}{|c|}{ I тайм } & \multicolumn{2}{|c|}{ II тайм } & & \\
\hline & & $\begin{array}{c}\text { к- } \\
\text { ть } \\
\text { дій }\end{array}$ & $\begin{array}{l}\text { коеф. } \\
\text { браку }\end{array}$ & $\begin{array}{c}\text { к-Tь } \\
\text { дій }\end{array}$ & $\begin{array}{c}\text { кое } \\
\phi . \\
\text { бра } \\
\text { ку }\end{array}$ & $\begin{array}{c}\text { к-ть } \\
\text { дій }\end{array}$ & $\begin{array}{c}\text { кое } \\
\phi . \\
\text { бра } \\
\text { ку }\end{array}$ & $\begin{array}{c}\text { к-ть } \\
\text { дій }\end{array}$ & $\begin{array}{l}\text { коеф. } \\
\text { браку }\end{array}$ & $\begin{array}{c}\text { к-Tь } \\
\text { дій }\end{array}$ & $\begin{array}{l}\text { коеф. } \\
\text { браку }\end{array}$ & $\begin{array}{c}\text { к-Tь } \\
\text { дій }\end{array}$ & $\begin{array}{l}\text { кое } \\
\text { ф. } \\
\text { бра } \\
\text { ку }\end{array}$ & $\begin{array}{c}\text { K-Tь } \\
\text { дій }\end{array}$ & $\begin{array}{l}\text { коеф. } \\
\text { браку }\end{array}$ \\
\hline \multicolumn{16}{|c|}{ 1/8 фіналу } \\
\hline 1 & Україна & $\begin{array}{l}16 / 1 \\
2 \\
\end{array}$ & $75 \%$ & $12 / 4$ & $33 \%$ & $\begin{array}{c}21 / 1 \\
2 \\
\end{array}$ & $57 \%$ & $\begin{array}{l}15 / 1 \\
0 \\
\end{array}$ & $66 \%$ & $25 / 5$ & $20 \%$ & $24 / 8$ & $33 \%$ & $\begin{array}{l}113 / \\
49 \\
\end{array}$ & $41 \%$ \\
\hline 2 & Швеція & $16 / 4$ & $25 \%$ & $11 / 7$ & $63 \%$ & $1 / 0$ & $0 \%$ & $6 / 1$ & $16 \%$ & $7 / 0$ & $0 \%$ & $0 \%$ & $0 \%$ & $\begin{array}{c}45 / \\
11\end{array}$ & $24 \%$ \\
\hline \multicolumn{16}{|c|}{ 1/4 фіналу } \\
\hline 1 & Україна & $5 / 3$ & $60 \%$ & $7 / 5$ & $71 \%$ & $\begin{array}{c}23 / 1 \\
4\end{array}$ & $61 \%$ & $14 / 6$ & $43 \%$ & $20 / 5$ & $25 \%$ & $13 / 5$ & $38 \%$ & $\begin{array}{l}82 / \\
38\end{array}$ & $46 \%$ \\
\hline 2 & Англія & $5 / 2$ & $40 \%$ & $7 / 2$ & $28 \%$ & $5 / 2$ & $40 \%$ & $9 / 1$ & $11 \%$ & $14 / 3$ & $21 \%$ & $17 / 1$ & $6 \%$ & $\begin{array}{c}57 / \\
11\end{array}$ & $19 \%$ \\
\hline
\end{tabular}




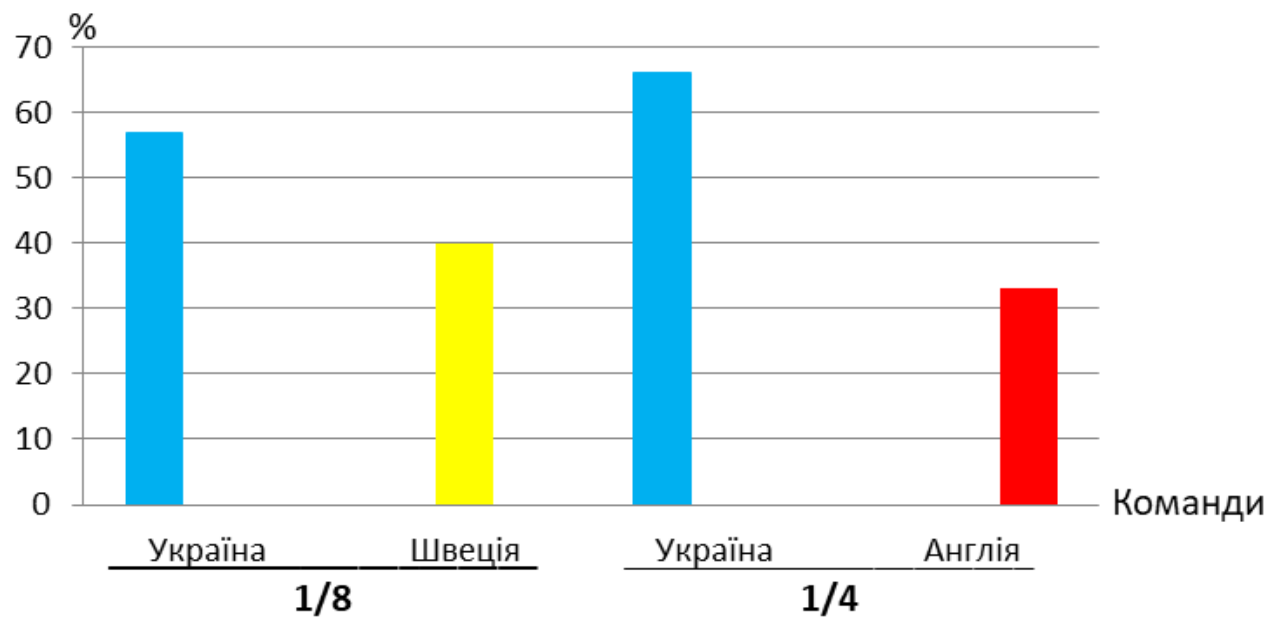

Рис.1.

Показники командного браку одноборств команд України, Швеції та Англії у 1/8, 1/4 чемпіонату Європи 2020-2021 рр.

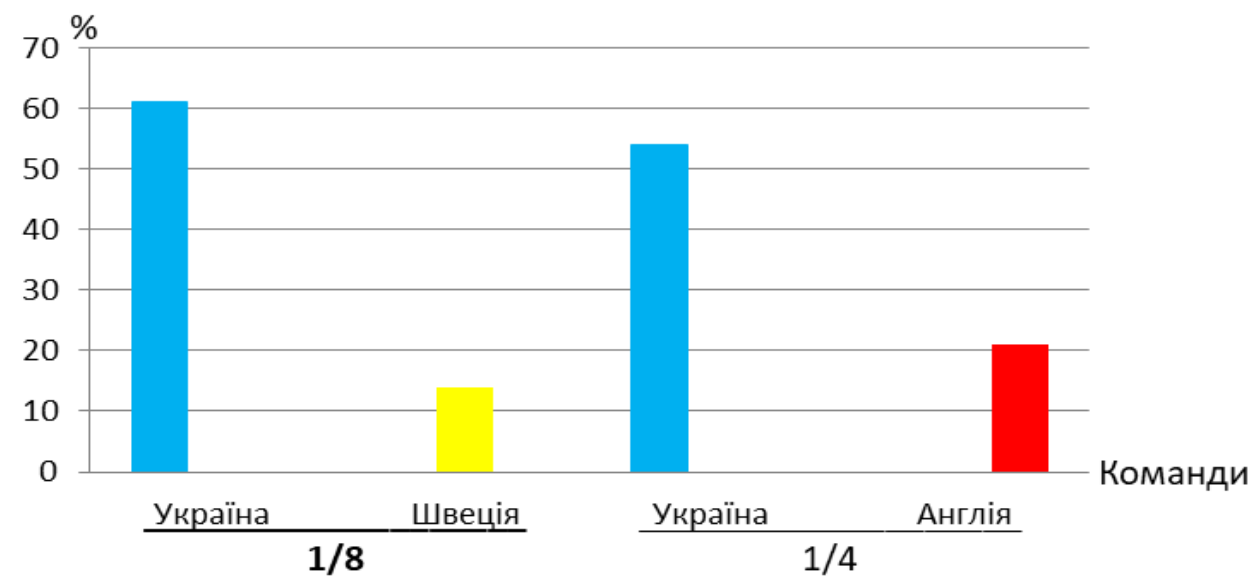

Рис.2.

Показники командного браку у відборах м'яча команд України, Швеції та Англії у 1/8, 1/4 чемпіонату Европи 2020-2021 рр.

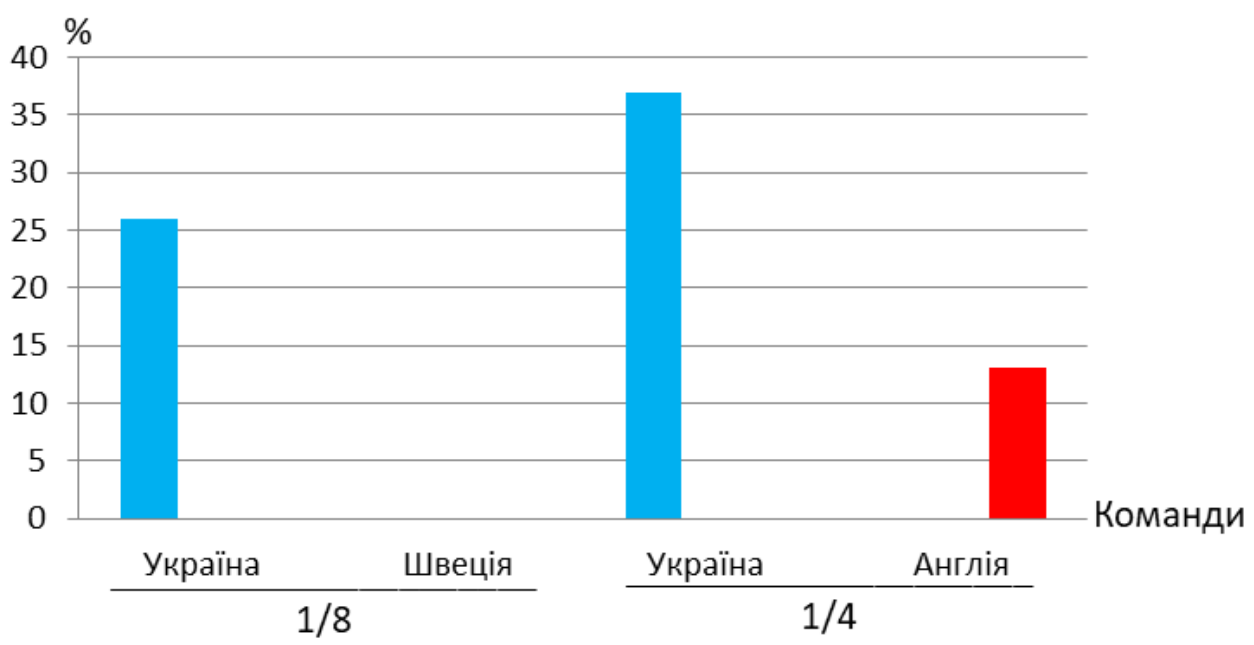

Рис. 3.

Показники у перехопленнях м'яча команд України, Швеції та Англії у 1/8, 1/4 фіналу чемпіонату Европи 2020-2021 pp. 


\begin{abstract}
Таблиця 2
Кількісні та якісні показники ударів по воротах команди України у 1/8 та у 1/4 чемпіонату Європи з командами Швеції та Англії (основний час)
\end{abstract}

\begin{tabular}{|c|l|c|c|}
\hline \multirow{2}{*}{ № } & \multirow{2}{*}{ Команди } & \multicolumn{2}{c|}{ За матч } \\
\cline { 3 - 4 } & \multicolumn{3}{|c|}{ удари } \\
\hline \multicolumn{3}{|c|}{ коефіціснт браку } \\
\hline 1 & Україна & $1 / 8$ фіналу \\
\hline 2 & Швеція & $15 / 11^{*}$ & $73 \%$ \\
\hline \multicolumn{3}{|c|}{$13 / 10^{*}$} \\
\hline 1 & Україна & $1 / 4$ фіналу \\
\hline 2 & Англія & $7 / 5^{*}$ & $71 \%$ \\
\hline
\end{tabular}

* загальна кількість ударів/кількість ударів, які не влучили уворота

відповідають модельним характеристикам, недивлячись на те, що зі збірною Швеції команда досягла позитивного результату (рис 1).

Одним з важливих компонентів захисних дій є відбори. Якість цих дій командою України, також суттєво відрізняється від показників збірної Швеції та Англії (рис 2).

що стосується перехоплень м'яча, то ці показники збірної України з усіх ТТД (одноборста, відбори, перехоплення) найкращі за якістю, але поступаються показникам збірної Швеції та Англії (рис 3).

у таблиці 2 наведено кількісні та якісні показники ударів збірної команди України зі збірною Швеції у 1/8 та зі збірною Англії у 1/4 чемпіонату Європи 2020-2021 рр.

Так, збірна України виконала всього 15 ударів, із них $з$ негативним показником - 11. Коефіцієнт браку склав - 73\%.

Збірна Швеції виконала всього 13 ударів, із них 10 з негативним показником. Коефіцієнт браку склав $77 \%$. Отримані результати кількості та якості ударів м'яча між командами України та Швеції значно не віздрізняються.

У матчі збірної України та Англії отримано такі показники: збірна України виконала всього 7 ударів, із них 5 - з негативним показником. Коефіцієнт браку склав 71\%; збірна Англії - 10 ударів, із них 4 - з негативним показником. Коефіцієнт браку склав 40 \%.
Треба відмітити, що з 6 ударів у отвір воріт, 4 удари були результативними.

На рис. 4 бачимо, що збірна України найбільшу кількість ударів виконала у грі зі збірною Швеції. Найменша кількість ударів виконана зі збірною Англії.

Коефіцієнт браку збірної України в ударах по воротах суттєво не відрізняється, у іграх з командою Швеції він склав 73\%, з командою Англії -71\%.

\section{Висновки / Дискусія}

Аналіз науково-методичної літератури за контролем ТТД футболістів високої кваліфікації є актуальним на сучасному етапі розвитку сучасного футболу.

Отримані кількісні та якісні показники виконання ТТД (одноборства, відбори, перехоплення, удари по воротах) збірної команди України в 1/8 з командою Швеції та у 1/4 з командою Англії на чемпіонаті Європи у 20202021 рр. свідчать про те, що збірна України мала значно вищі кількісні показники ТТД, але якість цих показників значно гірша, ніж у суперників.

Порівняльний аналіз якісних показників ТТД одноборства збірної команди України зі збірними Швеції та Англії свідчить, що вони не відповідають еталонним характеристикам, не дивлячись на те, що зі збірною Швеції команда України досягла позитивного результату.

Кількісні та якісні показники ударів по воротах команд України, Швеції та Англії у 1/8, 1/4 чемпіонату Европи 2020-2021 рр.

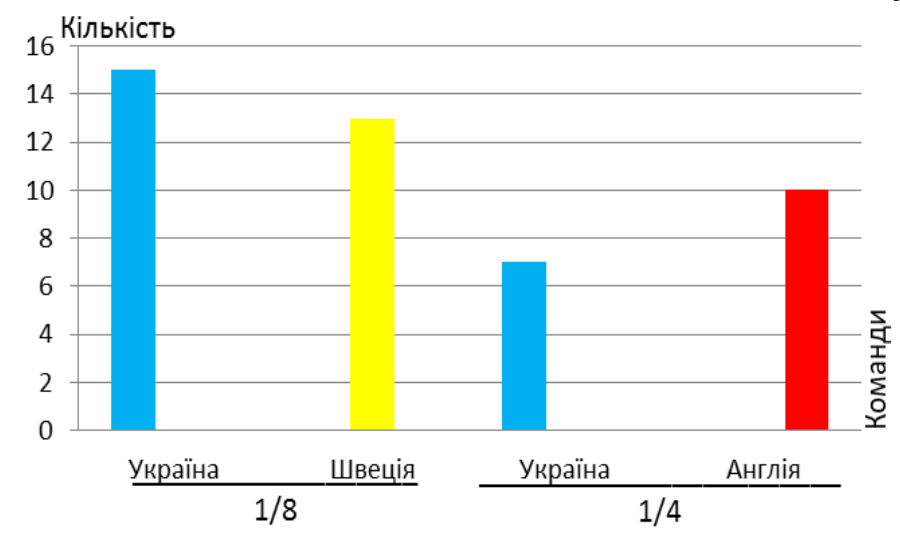

а) кількісні показники ударів

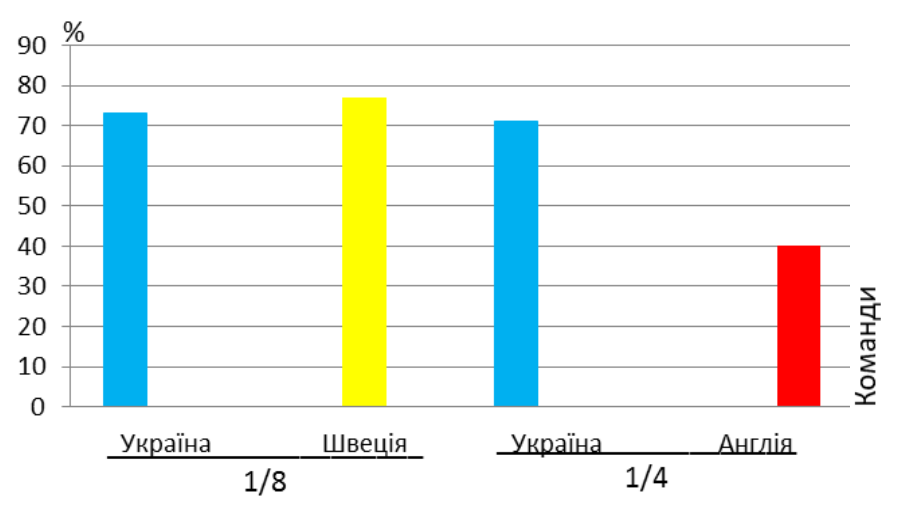

б) якісні показники ударів 
Перспективи подальших досліджень. Перспективи подальших досліджень вбачаємо у продовженні педагогічних спостережнь за змагальною діяльністю команд високої кваліфікації.

Конфлікт інтересів. Автори заявляють, що немає конфлікту інтересів, який може сприйматись таким, що завдасть шкоди неупередженості статті. Джерела фінансування. Ця стаття не отримала фінансової підтримки від державної, громадської або комерційної організації.

\section{Список посилань}

1. Аверьянов А. А. (2004), «Анализ технико-тактических действий полузащитников соборной Франции в играх Первенства Европы 2000 г.», Теория и практика футбола, №1 (21), С. 8-11.

2. Бузник А. И., Джус О. Н. (2001), Инструкция по работе научно-методических групп в неаматорских командах: научнометодический комитет федерации футбола Украины. Киев, 40 с.

3. Журид С. Н. (2007), «Совершенствование технико-тактических действий юных футболистов 15-17 лет различных игровых амплуа», Слобожанський науково-спортивний вісник, №12, С. 93-97.

4. Лисенчук Г. А. (2003), Управление подготовтовкой футболистов. Київ: Олімпійська література, 271 с.

5. Люкшинов Н. М. (2003), Исскуство подготовки высококласных футболистов. Москва: Советский спорт, 416 с.

6. Перевозник В., Паевский В. (2018), «Особенности технико-тактических действий команды «Металлист» в играх лиги Европы», Слобожанський науково-спортивний вісник, №1 (63), С. 61-64.

7. Перевозник В. І., Паєвський В. В. (2018), «Порівняльний аналіз команд групового турніру фіналу чемпіонатів світу з футболу 2014, 2018 рр.», Науковий часопис Національного педагогічного університету імені М. П. Драгоманова. Серія 15. Науковопедагогічні проблеми фізичної культури (фізична культура і спорт), Випуск 5 (113), С.117-123.

8. Перцухов А. А. (2018), «Характеристика результативных ударов в ворота в играх команды первой лиги первенства Украины «Гелиос» Харьков», Слобожанський науково-спортивний вісник, №1 (63), С. 65-69.

9. Перцухов А. А., Шаленко В. В. (2017), «Характеристика ударов в ворота в играх команд вісокой квалификации», Науковий часопис Національного педагогічного університету імені М. П. Драгоманова. Серія 15. Науково-педагогічні проблеми фізичної культури (фізична культура і спорт), Випуск 12 (94), С. 79-84.

10. Футбол: Учебник для институтов физической культуры (1999), под ред. Полишкиса М.С., Выжгина В.А. Москва: Физкультура, образование и наука, 254 с.

11. Шаленко В. В., Перцухов А. А. (2012), «Особливості виконання ударів у ворота в іграх команд високої кваліфікації», Слобожанський науково-спортивний вісник, №1, С. 76-80.

12. Gero Bisanz \& Gerisch Gunnar (2008), Fussball. Kondition-Technik-Taktik und Coaching. Aachen: Verlag Meyer\&Meyer, 560 p.

13. Kopera K., Sledziewski L. (1997), Pilka noźna : unificacja procesu szkolenia dzieci i mlodziezy. Warszawa, 134 p.

14. Szyngier W., Gumola W. (2009), «Monitorowanie treningu piłkarzy nożnych o rożnym poziomie zaawansowania sportowego», Teoretyczne i praktyczne aspekty nowoczesnej gry w pilkę nożną. Opole, pp. 177 - 192.

15. Szwarc A. (2003), Metody oceny techniczno-taktycznych działań piłkarzy nożnych: AWFiS, 158 p.

Стаття надійшла до редакції: 05.08.2021 p.

Опубліковано: 31.08.2021 p.

Аннотация. Владимир Перевозник, Владимир Паевский. Показатели технико-тактических действий (единоборства, отборы, перехваты, удары) сборной команды Украины в играх 1/8 и 1/4 чемпионата Европы в 2020-2021 гг. Цель: провести сравнительный анализ показателей технико-тактических действий (единоборства, отборы, перехваты, удары по воротам) сборной команды Украины в 1/8 с командой Швейцарии и в 1/4 с командой Англии в чемпионате Европы. Материал и методы: теоретический анализ и обобщение данных научно-методической литературы, методы педагогических наблюдений, методы математической статистики, регистрации и сравнительных анализ технико-тактических действия (единоборства, отборы, перехваты, удары по воротам) сборной команды Украины в 1/8 с командой Швеции и с командой Англии в 1/4 чемпионата Европы в 2020-2021 гг. Результаты: проведён количественный и качественный анализ показателей технико-тактических действий (единоборства, отборы, перехваты, удары по воротам) сборной команды Украины в 1/8 со сборной Швеции и с командой Англии в 1/4 чемпионата Европы в 2020-2021 гг. Выводы: получены количественные и качественные показатели выполнения ТТД (единоборства, отборы, перехваты, удары по воротам) сборной команды Украины в 1/8 с командой Швеции и в 1/4 с командой Англии на чемпионате Европы в 2020-2021 гг., которые свидетельствуют о том, что сборная команда Украины имела значительно выше количественные показатели ТТД, но качество этих показателей значительно хуже, чем у конкурентов. Сравнительный анализ качественных показателей ТТД (единоборства), сборной команды Украина со сборными Швеции и Англии свидетельствует о том, что они не соответствуют модельным характеристикам, несмотря на то, что со сборной Швеции команда Украины достигла положительного результата.

Ключевые слова: технико-тактические действия, единоборства, футболисты, коэффициент брака.

Abstract. Volodymyr Perevoznyk, Volodymyr Paievskyi. Indicators of technical and tactical actions (combat sports, tackles, interceptions, kicks) of the Ukrainian national team in the games of 1/8 and 1/4 of the European Championship in 2020-2021. Purpose: to conduct a comparative analysis of the indicators of technical and tactical actions (single combats, tackles, interceptions, kicks on goal) of the Ukrainian national team in 1/8 with the Swiss team and 1/4 with the England team in the European Championship. Material and methods: theoretical analysis and generalization of scientific and methodological literature data, methods 


\section{СЛОБОЖАНСЬКИЙ НАУКОВО-СПОРТИВНИЙ ВІСНИК}

of pedagogical observation, methods of mathematical statistics, registration and comparative analysis of technical and tactical actions (combat sports, tackles, interceptions, kicks on goal) of the Ukrainian national team in 1/8 with the Swedish team and the England team in the 1/4 of the European Championship in 2020-2021. Results: a quantitative and qualitative analysis of indicators of technical and tactical actions (combat sports, tackles, interceptions, kicks on goal) of the Ukrainian national team in 1/8 with the Swedish national team and 1/4 with the England team in 1/4 of the European Championship 2020-2021 was carried out. Conclusions: the obtained quantitative and qualitative indicators of the performance of TTD (combat sports, tackles, interceptions, kicks on goal) of the Ukrainian national team in 1/8 with the Swedish team and in 1/4 with the England team at the European Championship 2020-2021 indicate that the national team of Ukraine had significantly higher quantitative indicators of TTD, but the quality of these indicators is much worse than that of competitors. A comparative analysis of the qualitative indicators of TTD (combat sports), the Ukraine national team with the Sweden and England national teams shows that they do not correspond to the model characteristics, despite the fact that the Ukrainian team achieved a positive result with the Swedish national team.

Keywords: technical and tactical actions, combat sports, football players, defect rate.

\section{References}

1. Aver'yanov, A. A. (2004), «Analysis of technical and tactical actions of the midfielders of Cathedral France in the games of the European Championship in 2000», Teoriya i praktika futbola, №1 (21), pp. 8-11. (in Russ.).

2. Buznik, A. I., Dzhus, O. N. (2001), Instruktsiya po rabote nauchno-metodicheskikh grupp v neamatorskikh komandakh: nauchnometodicheskiy komitet federatsii futbola Ukrainy. Kiyev, 40 p. (in Russ.).

3. Zhurid, S. N. (2007), «Improving the technical and tactical actions of young footballers 15-17 years old of different game roles», Slobozhans'kiy naukovo-sportivniy vísnik, №12, pp. 93-97. ( in Russ.).

4. Lysenchuk, H. A. (2003), Upravlenye podhotovtovkoy futbolystov. Kyyiv: Olimpiys'ka literatura, 271 p. (in Russ.).

5. Lyukshinov, N. M. (2003), Iskusstvo podgotovki vysokoklassnykh futbolistov. Moskva: Sovetskiy sport, 416 p. (in Russ.).

6. Perevoznik, V., Payevskiy, V. (2018), «Features of technical and tactical actions of the Metalist team in the games of the Europa League», Slobozhans'kiy naukovo-sportivniy vísnik, №1 (63), pp. 61-64. (in Russ.).

7. Perevoznyk, V. I., Payevs'kyy, V. V. (2018), "Comparative analysis of the teams of the group tournament of the finals of the World Cup 2014, 2018», Naukovyy chasopys Natsional'noho pedahohichnoho universytetu imeni M. P. Drahomanova. Seriya 15. Naukovopedahohichni problemy fizychnoyi kul'tury (fizychna kul'tura i sport), Vypusk 5 (113), pp.117-123. (in Ukr.).

8. Pertsukhov, A. A. (2018), "Characteristics of effective strikes into the goal in the games of the team of the first league of the championship of Ukraine» Helios «Kharkiv», Slobozhans’kiy naukovo-sportivniy vísnik, №1 (63), pp. 65-69. (in Russ.).

9. Pertsukhov, A. A., Shalenko, V. V. (2017), "Characteristics of shots on goal in the games of highly qualified teams», Naukovyy chasopys Natsional'noho pedahohichnoho universytetu imeni M. P. Drahomanova. Seriya 15. Naukovo-pedahohichni problemy fizychnoyi kul'tury (fizychna kul'tura i sport), Vypusk 12 (94), pp. 79-84. (in Russ.).

10. Futbol: Uchebnik dlya institutov fizicheskoy kul'tury (1999), pod red. Polishkisa M.S., Vyzhgina V.A. Moskva: Fizkul'tura, obrazovaniye i nauka, 254 p. (in Russ.).

11. Shalenko V. V., Pertsukhov A. A. (2012), «Peculiarities of goal kicks in games of highly qualified teams», Slobozhans'kyy naukovosportyvnyy visnyk, №1, pp. 76-80. (in Russ.).

12. Gero, Bisanz \& Gerisch, Gunnar (2008), Fussball. Kondition-Technik-Taktik und Coaching. Aachen: Verlag Meyer\&Meyer, 560 p. (in Eng.).

13. Kopera, K., Sledziewski, L. (1997), Pilka noźna : unificacja procesu szkolenia dzieci i mlodziezy. Warszawa, 134 p. (in Eng.).

14. Szyngier, W., Gumola, W. (2009), «Monitorowanie treningu piłkarzy nożnych o rożnym poziomie zaawansowania sportowego», Teoretyczne i praktyczne aspekty nowoczesnej gry w pilkę nożną. Opole, pp. 177 - 192. (in Eng.).

15. Szwarc, A. (2003), Metody oceny techniczno-taktycznych działań piłkarzy nożnych: AWFiS, 158 p. (in Eng.).

Received: 05.08.2021.

Published: 31.08.2021

\section{Відомості про авторів / Information about the Authors}

Перевозник Володимир Іванович: к. Фіз.вих., доцент; Харківська державна академія фізичної культури: вул. Клочківська,

99, м. Харків, 61058, Україна.

Перевозник Владимир Иванович: к. физ.восп., доцент; Харьковская г. Харьков, 61058, Украина.

Volodymyr Perevoznyk: PhD (Physical Education and Sport), Associate Professor; Kharkiv State Academy of Physical Culture: Klochkivska 99, Kharkiv, 61058, Ukraine.

ORCID: http://orcid.org/0000-0001-6798-1497

E-mail: v.perevoznik60@mail.ru

Паєвський Володимир Валерійович: к.фіз.вих., доцент; Харківська державна академія фізичної культури: вул. Клочківська, 99. м. Харків, 61058, Україна.

Паевский Владимир Валерьевич: к.физ.восп., доцент; Харьковская государственная академия физической культуры: ул. Клочковская, 99, г. Харьков, 61058, Украина.

Volodymyr Paievskyi: PhD (Physical Education and Sport), Associate Professor; Kharkiv State Academy of Physical Culture: Klochkivska str. 99, Kharkiv, 61058, Ukraine.

ORCID: http://orcid.org/0000-0002-9068-1422

E-mail: v.paevskiy1971@gmail.com 